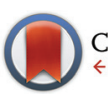

CrossMark \& click for updates

Cite this: Dalton Trans., 2016, 45 8556

Received 17th February 2016, Accepted 14th April 2016

DOI: $10.1039 /$ c6dt00654j www.rsc.org/dalton

\title{
Supramolecular exo-functionalized palladium cages: fluorescent properties and biological activity $\dagger$
}

\author{
Andrea Schmidt, ${ }^{\text {a,b }}$ Manuela Hollering, ${ }^{a}$ Markus Drees, ${ }^{a}$ Angela Casini ${ }^{b}$ and \\ Fritz E. Kühn*a
}

\begin{abstract}
Metallosupramolecular systems are promising new tools for pharmaceutical applications. Thus, novel selfassembled $\mathrm{Pd}(॥)$ coordination cages were synthesized which were exo-functionalized with naphthalene or anthracene groups with the aim to image their fate in cells. The cages were also investigated for their anticancer properties in human lung and ovarian cancer cell lines in vitro. While the observed cytotoxic effects hold promise and the cages resulted to be more effective than cisplatin in both cell lines, fluorescence emission properties were scarce. Therefore, using TD-DFT calculations, fluorescence quenching observed in the naphthalene-based system could be ascribed to a lower probability of a HOMO-LUMO excitation and an emission wavelength outside the visible region. Overall, the reported $\mathrm{Pd}_{2} \mathrm{~L}_{4}$ cages provide new insights into the chemical-physical properties of this family of supramolecular coordination complexes whose understanding is necessary to achieve their applications in various fields.
\end{abstract}

\section{Introduction}

Coordination-driven self-assembly is an ideal method for constructing discrete, two- and three-dimensional metal-based entities. ${ }^{1}$ These supramolecular coordination complexes (SCCs) with well-defined geometries and cavities have found applications not only in host-guest chemistry ${ }^{2}$ and catalytic reactions, ${ }^{3}$ but also in biochemistry and medicine. ${ }^{4}$ For medicinal purposes, SCCs have been developed as drug delivery vehicles ${ }^{5-7}$ to recognize and interact with biomolecules ${ }^{8}$ and to function as anticancer agents. ${ }^{9-11}$

Notably, Therrien et al. reported the first coordination cage, a ruthenium-arene metallocage, used as a drug delivery system for Pd and Pt acetylacetonato complexes, showing anticancer effects in cancer cell line A2780. ${ }^{6}$ In further studies, ruthenium-arene metallocages displayed increased cytotoxic effects in human lung cancer cells compared to cisplatin, thus acting as anticancer drugs per se. ${ }^{11}$ Interestingly, the first toxicity studies in vivo of SCCs as anticancer compounds were per-

\footnotetext{
${ }^{a}$ Molecular Catalysis, Catalysis Research Center and Department of Chemistry, Technische Universität München, Lichtenbergstr. 4, 85747 Garching bei München, Germany.E-mail: fritz.kuehn@ch.tum.de

${ }^{b}$ Medicinal and Bioinorganic Chemistry, School of Chemistry, Cardiff University, Park Place, CF103AT Cardiff, UK. E-mail: casinia@cardiff.ac.uk

$\dagger$ Electronic supplementary information (ESI) available: ${ }^{1} \mathrm{H}$ NMR, ESI-MS, excitation spectra, crystallographic details and DFT calculations. CCDC 1454096. For ESI and crystallographic data in CIF or other electronic format see DOI: 10.1039/ c6dt00654j
}

formed with rhomboidal platinum(II) assemblies showing an effect on the reduction of the tumor growth rate in mice. ${ }^{10}$

A specific and attractive area of SCCs is the self-assembly of $\mathrm{M}_{2} \mathrm{~L}_{4}(\mathrm{M}=$ metal, $\mathrm{L}=$ ligand $)$ metallocages, ${ }^{12}$ which can enclose a variety of small molecules within their cavity, such as ions ${ }^{13}$ and neutral molecules. ${ }^{14}$ In addition, the properties of the $\mathrm{M}_{2} \mathrm{~L}_{4}$ coordination cages can be optimized by functionalization of the ligand framework.

Up to now, only a few reports on the biological properties of $\mathrm{Pd}_{2} \mathrm{~L}_{4}$ complexes have appeared. ${ }^{5,15}$ Recently, we investigated fluorescent palladium cages as drug delivery systems for cisplatin, which proved to be active in cancer cells, while poorly toxic ex vivo in healthy rat liver tissues. ${ }^{5}$ The obtained metallocages showed fluorescence properties due to the used ligand system, namely exo-functionalized bipyridyl ligands. However, upon cage formation, a significant quenching of the ligands' fluorescence occurred due to the binding to $\mathrm{Pd}^{2+}$ ions. The extremely low quantum yield of this first series of cages prevented their study of cellular uptake via fluorescence microscopy in most cases. Indeed, nearly all capsules and cages composed of coordination metal-ligand bonds are non-emissive due to quenching by the heavy transition metal ions. ${ }^{16}$ Only in a few cases, highly fluorescent $\mathrm{M}_{2} \mathrm{~L}_{4}$ cages were obtained. ${ }^{17,18}$

However, fluorescent metal-based entities would be very attractive in the medicinal inorganic chemistry field, to achieve their imaging in biological environments via fluorescence microscopy. In fact, an increasing number of reports on anticancer metal compounds bearing fluorescent moieties 


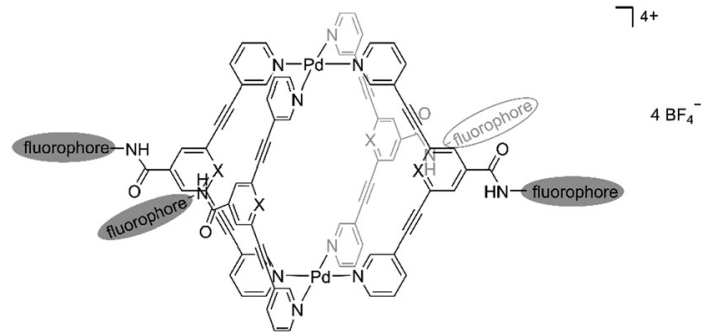

Fig. 1 Schematic structure of $\mathrm{Pd}_{2} \mathrm{~L}_{4}$ cage compound 1 attached to fluorophore moieties.

for both therapeutic and imaging applications have appeared. $^{19}$ The reported metal-based compounds include fluorescent $\mathrm{Ru}$ polypyridine complexes, ${ }^{20}$ as well as several organometallic compounds among others. ${ }^{21}$

Therefore, in this work, in order to obtain cytotoxic metallocages with improved fluorescence properties, we designed a new series of self-assembled exo-functionalized $\operatorname{Pd}_{2} \mathrm{~L}_{4}$ cages coupled to fluorescent groups. The main structural motif of the $\operatorname{Pd}_{2} \mathrm{~L}_{4}$ cage compound $\mathbf{1}$ attached to naphthalene or anthracene moieties is shown in Fig. 1. In addition, a cage featuring a carboxy group in the exo-position was also included for comparison purposes to better characterize the effects of the bulky fluorescent tags on the biological properties of metallocages. Thus, the photophysical properties of cage compounds and ligands were investigated and DFT calculations were performed to rationalize the observed spectroscopic properties. In addition, the cages and respective ligands were studied for their antiproliferative effects in human cancer cell lines in vitro.

\section{Results and discussion}

\section{Synthesis and characterization}

Rigid bidentate alkyne-based ligands $\mathbf{2 a - 2 c}$ attached to fluorophores were synthesized in a two-step synthesis relying on amide bond formation and a Sonogashira cross-coupling reaction (Scheme 1). The dibromo derivatives 3a-3c were obtained in yields ranging from 54 to $98 \%$ by treatment of the acid with

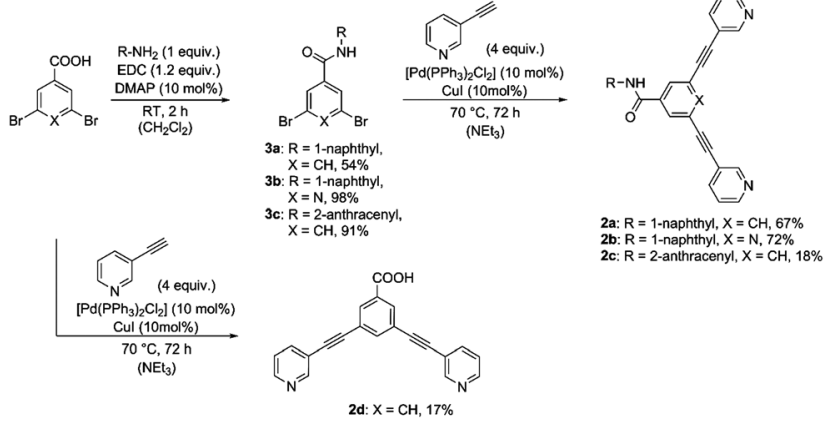

Scheme 1 Synthesis of ligands 2a-d via Sonogashira cross coupling. naphthyl- or anthracenyl-based amines in the presence of a coupling reagent EDC and DMAP as a base. Compounds $\mathbf{3 a - 3 \mathbf { c }}$ were coupled with 3-ethynylpyridine using Sonogashira conditions to give the ligands $2 a-2 c$ in 18 to $72 \%$ yield. In order to evaluate the optical and biological properties of fluorophorebased compounds compared to a non-fluorophore system, carboxy-functionalized ligand $\mathbf{2 d}$ was prepared in $17 \%$ yield by coupling 3,5-dibromobenzoic acid with 3-ethynylpyridine using a Sonogashira reaction (Scheme 1).

The reaction of bidentate ligands $\mathbf{2 a - 2 d}$ and a palladium precursor $\left[\mathrm{Pd}\left(\mathrm{NCCH}_{3}\right)_{4}\right]\left(\mathrm{BF}_{4}\right)_{2}$ in a $2: 1$ ligand: metal ratio in DMSO at room temperature for $1 \mathrm{~h}$ yielded cage compounds $\left[\mathrm{Pd}_{2}(2)_{4}\right]\left(\mathrm{BF}_{4}\right)_{4} \mathbf{1 a - 1 d}$ in 63 to $81 \%$ (Scheme 2). Successful cage formation was studied by ${ }^{1} \mathrm{H}$ and DOSY NMR spectroscopy, ESI mass spectrometry and single crystal X-ray diffraction.

The ${ }^{1} \mathrm{H}$ NMR spectra of naphthalene-based ligand $\mathbf{2 a}$, carboxy-based ligand $\mathbf{2 d}$ and their corresponding cages $\mathbf{1 a}$ and 1d are exemplarily depicted in Fig. 2. Upon cage formation, the pyridyl proton signals $\left(\mathrm{H}_{\mathrm{a}}-\mathrm{H}_{\mathrm{d}}\right)$ experience a significant downfield shift, especially the signals of $\mathrm{H}_{\mathrm{a}}$ and $\mathrm{H}_{\mathrm{b}}$, which are shifted by ca. 1 ppm. However, the proton signals of naphthalene and anthracene moieties are not affected by the coordination of the pyridyl group to palladium.

Diffusion-ordered NMR spectroscopy (DOSY) provides additional evidence for the successful cage formation in solution (Table 1). ${ }^{1} \mathrm{H}$ DOSY measurements of the cages $1 \mathbf{a}-\mathbf{d}$ and of the ligands $2 \mathbf{a}-\mathbf{d}$ show diffusion coefficients $(D)$ in the range of 0.81 to $0.90 \times 10^{-10} \mathrm{~m}^{2} \mathrm{~s}^{-1}$ and 1.76 to $2.02 \times 10^{-10} \mathrm{~m}^{2} \mathrm{~s}^{-1}$, respectively, resulting in $D_{\text {ligand }} / D_{\text {complex }}$ ratios of about $2: 1$, which are in accordance with the literature values. ${ }^{5,17}$ In addition, DOSY NMR was used to estimate the size of the cage compounds applying the Stokes-Einstein equation. ${ }^{22}$ The hydrodynamic radii $r_{\mathrm{s}}$ of the cage compounds were determined to be between 1.2 and $1.4 \mathrm{~nm}$.

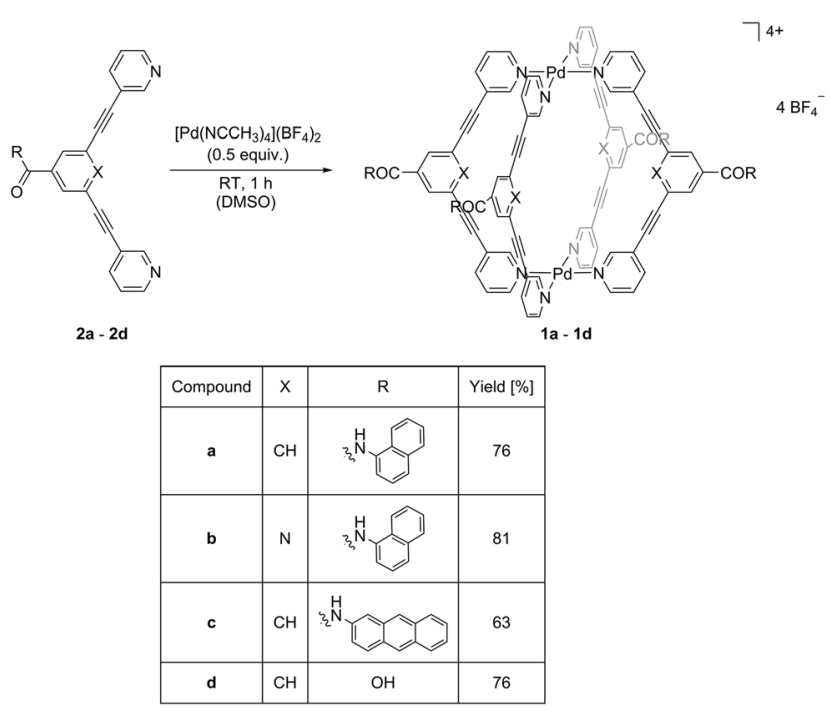

Scheme 2 Synthesis of palladium(II) cages 1a-d via self-assembly using bidentate ligands $2 a-d$ and $\left[\mathrm{Pd}\left(\mathrm{NCCH}_{3}\right)_{4}\right]\left(\mathrm{BF}_{4}\right)_{2}$ as a precursor. 


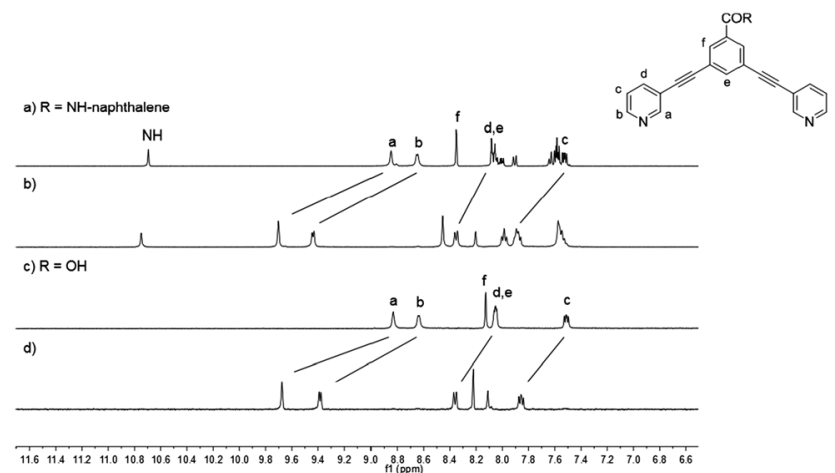

Fig. 2 Stacked ${ }^{1} \mathrm{H}$ NMR spectra (400 MHz, $\left.\left[\mathrm{D}_{6}\right] \mathrm{DMSO}\right)$ of ligand $2 \mathrm{a}(\mathrm{a})$, cage $1 \mathrm{a}(\mathrm{b})$, ligand $2 \mathrm{~d}(\mathrm{c})$ and cage $1 \mathrm{~d}(\mathrm{~d})$.

Table 1 Comparison of diffusion coefficients $\left(D \times 10^{-10} \mathrm{~m}^{2} \mathrm{~s}^{-1}\right)$ of ligands and palladium cages obtained by ${ }^{1} \mathrm{H}$ DOSY NMR $\left(400 \mathrm{MHz},\left[\mathrm{D}_{6}\right]\right.$ DMSO)

\begin{tabular}{lllll}
\hline Cage & $D$ of cage & Ligand & $D$ of ligand & Ratio \\
\hline 1a & 0.90 & 2a & 2.02 & 2.25 \\
1b & 0.88 & 2b & 1.76 & 2.00 \\
1c & 0.81 & 2c & 1.77 & 2.19 \\
1d & 0.87 & 2d & 2.02 & 2.32
\end{tabular}

The formation of $\mathrm{Pd}_{2} \mathrm{~L}_{4}$ cages was further confirmed by ESI-MS spectrometry showing isotopically resolved peaks of $\left[\mathrm{Pd}_{2}(2)_{4}\right]^{4+}$ and $\left[\mathrm{Pd}_{2}(2)_{4} \mathrm{BF}_{4}\right]^{3+}$. For instance, the MS signals of cage $1 \mathbf{d}$ at $m / z 378.0$ and 532.4 were assigned to the fragments $\left[\mathbf{1 d}-4 \mathrm{BF}_{4}{ }^{-}\right]^{4+}$ and $\left[\mathbf{1 d}-3 \mathrm{BF}_{4}{ }^{-}\right]^{3+}$, respectively (Fig. 3).

Single-crystal X-ray diffraction provided structural verification of cage $\mathbf{1 b}$ (Fig. 4). Suitable single crystals of $\mathbf{1 b}$ were grown by vapor diffusion of diethyl ether into a DMF solution of the cage. The crystal structure revealed the $\operatorname{Pd}_{2} \mathrm{~L}_{4}$ cage configuration in which the four bidentate ligands $\mathbf{2 b}$ are coordinated to two $\mathrm{Pd}(\mathrm{II})$ ions in a square-planar fashion. The cavity size is defined by the Pd...Pd distance of $11.9 \AA$ and by the distance between the two opposing pyridyl moieties of $10.5 \AA$ A. Based on spectroscopic evidence it can be assumed that the solid-state structures of cages $\mathbf{1 a}, \mathbf{1 b}, \mathbf{1 c}$ and $\mathbf{1 d}$ are similar.

The palladium cages 1a-d are stable for months under air and light in both the solution and solid state. The cage compounds are soluble in DMSO and DMF, as well as in mixtures of DMF/acetone, DMSO/acetonitrile and DMSO/water, and not soluble in less polar solvents. The cages are soluble in water up to a concentration of $100 \mu \mathrm{M}$.

\section{Optical properties and DFT calculations}

As previously mentioned, the photophysical properties of metallocages, particularly the emissive ones, are of special interest to follow the uptake and distribution of cages in cells by fluorescence microscopy. The absorption and emission

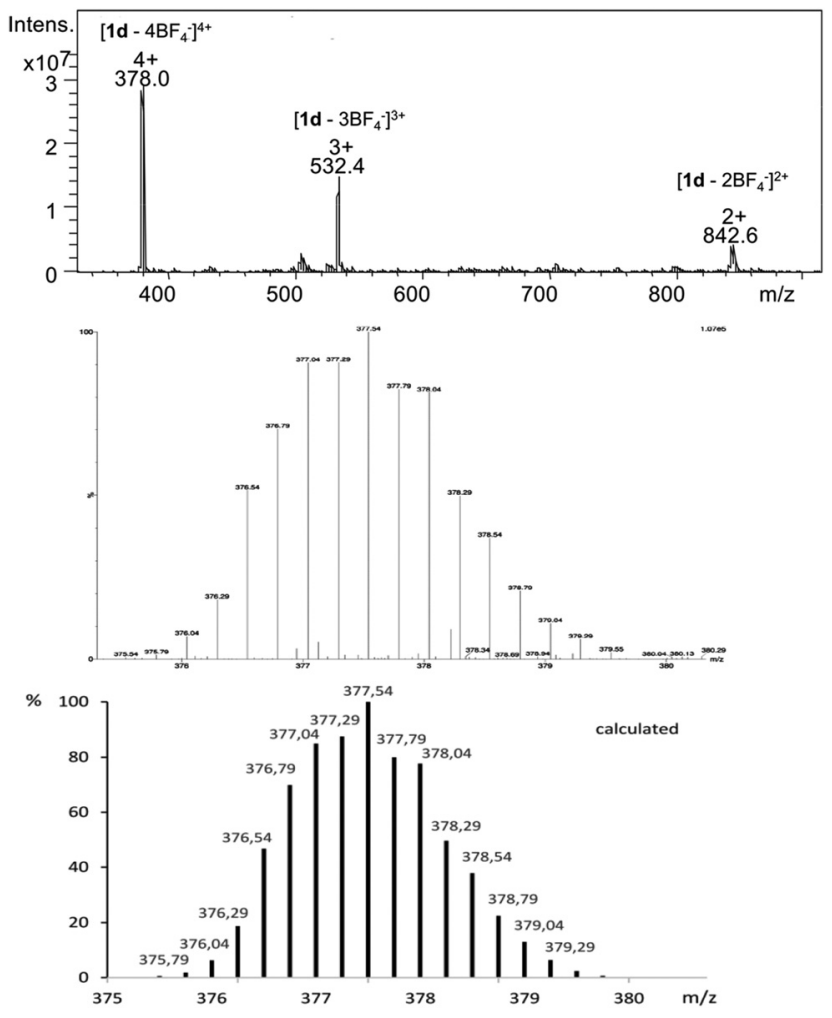

Fig. 3 ESI mass spectrum of cage $1 \mathrm{~d}$ (top), measured isotopic pattern of the molecule signal $\left[1 \mathrm{~d}-4 \mathrm{BF}_{4}^{-}\right]^{4+}$ (middle) and calculated isotopic distribution (bottom).

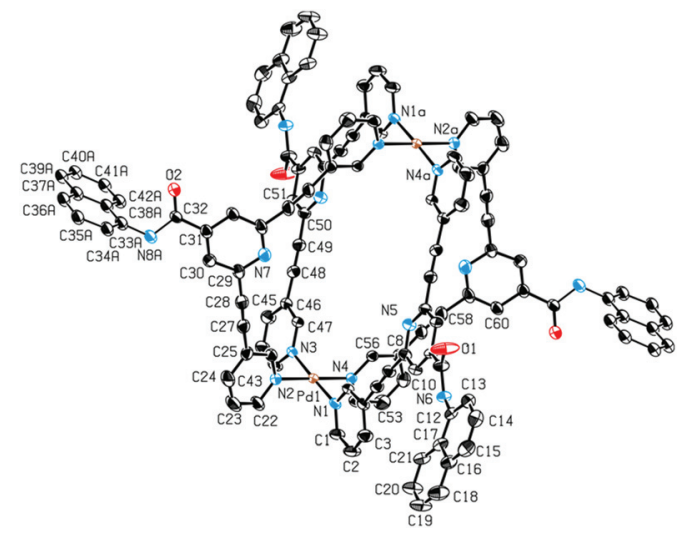

Fig. 4 Solid state molecular structure of $1 \mathrm{~b}$. Ellipsoids are shown at the $50 \%$ probability level. Hydrogen atoms, counterions and solvent molecules are omitted for clarity. Selected bond lengths $(\AA)$ and angles $\left(^{\circ}\right)$ :

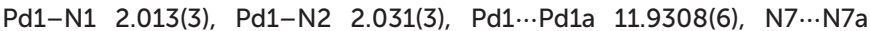
10.5029(6), N1-Pd1-N2 88.54(12), N2-Pd1-N3 92.45(12).

properties of our series are shown in Table 2 while the corresponding spectra are depicted in Fig. 5 and 6. The excitation spectra are shown in the ESI. $\dagger$

The UV-Vis spectra of cages display strong ligand-based absorption bands in the range of 260-350 nm deriving from $\pi-\pi^{*}$ transitions of the highly conjugated ligands. The cages 
Table 2 UV-Vis absorbance and fluorescence emission properties of palladium cages and ligands

\begin{tabular}{|c|c|c|c|c|c|}
\hline Compound & $\varepsilon_{\max }\left[\mathrm{L} \mathrm{mol}^{-1} \mathrm{~cm}^{-1}\right]$ & $\lambda_{\max }(\mathrm{abs})[\mathrm{nm}]$ & $\lambda(\mathrm{ex})[\mathrm{nm}]$ & $\lambda_{\max }(\mathrm{em})[\mathrm{nm}]$ & $\Phi^{a}[\%]$ \\
\hline $1 \mathrm{a}$ & 216000 & 291,311 & 330 & 370 & $0.3 \pm 0.02$ \\
\hline $2 \mathbf{a}$ & 68100 & 290,306 & 325 & 370 & $0.4 \pm 0.03$ \\
\hline $2 \mathbf{b}$ & 36700 & 287,329 & 305 & 375,450 & $0.2 \pm 0.02$ \\
\hline $1 \mathrm{c}$ & 256800 & $291,309,381$ & 330 & - & - \\
\hline $2 \mathrm{c}$ & 73700 & 290,310 & 280 & 430 & $0.2 \pm 0.01$ \\
\hline 1d & 136600 & 288,310 & 280 & 355 & $1.2 \pm 0.07$ \\
\hline
\end{tabular}

${ }^{a}$ Mean \pm probable error of three measurements.

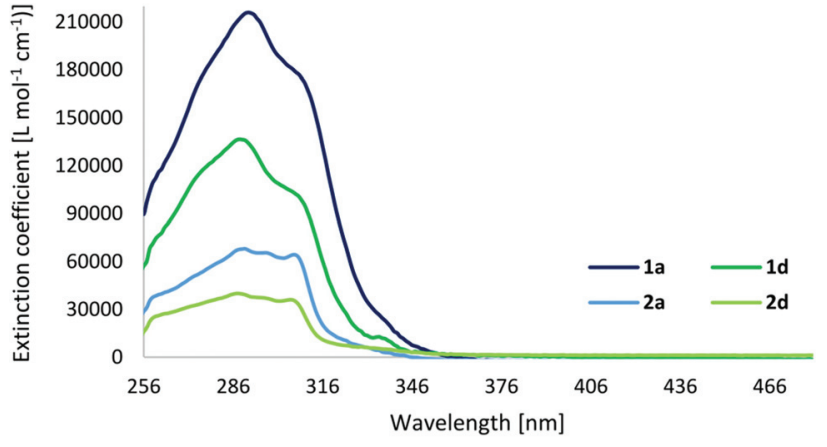

Fig. 5 Absorption spectra of cage compounds $1 \mathrm{a}$ and $1 \mathrm{~d}$, and ligands $2 \mathrm{a}$ and $2 \mathrm{~d}$ in DMSO $\left(c=5 \times 10^{-6} \mathrm{M}\right.$ and $\left.10^{-5} \mathrm{M}\right)$.

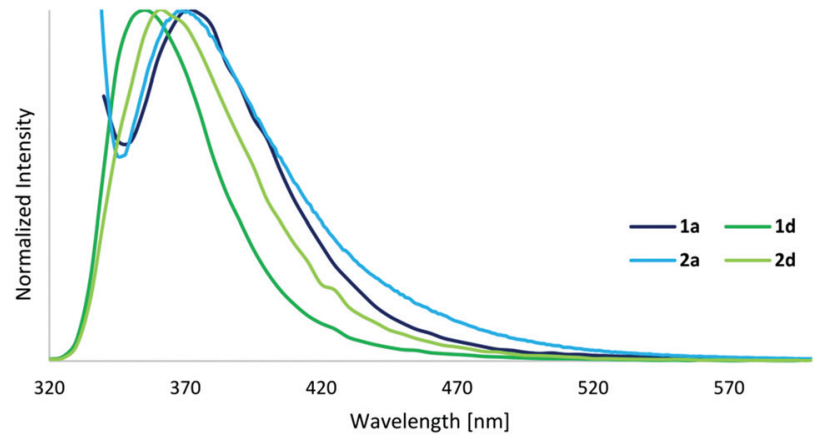

Fig. 6 Emission spectra of cage compounds $1 \mathrm{a}$ and $1 \mathrm{~d}(\lambda(\mathrm{ex})=330 /$ $280 \mathrm{~nm})$, and ligands $2 \mathrm{a}$ and $2 \mathrm{~d}(\lambda(\mathrm{ex})=325 / 280 \mathrm{~nm})$ in DMSO $\left(c=10^{-5} \mathrm{M}\right)$.

exhibit a three- to four-times higher extinction coefficient compared to their respective ligands. As normally observed for this type of cage compound, the carboxy-based ligand $\mathbf{2 d}$ (with a quantum yield of $8 \%$ ) presents a significant quenching of the fluorescence upon cage formation, resulting in quantum yields of $1 \%$ for $\mathbf{1 d}$. However, in contrast to our expectations, the fluorophore-based ligands and cages display fluorescence quantum yields even lower, below 1\%, and the anthracenebased cage 1c exhibits no fluorescence at all.

In order to investigate the unexpected photophysical properties of fluorophore-based systems, a time-dependent density functional theory (TD-DFT) approach was used to calculate the probability of the HOMO-LUMO excitation and the emission wavelength. Also, the absorption and fluorescence properties of the naphthalene-based ligand $2 \mathbf{a}(\Phi<1 \%)$ were compared with those of the carboxy- and amine-based ligands 2d and 2e ( $\Phi=8$ and $52 \%,{ }^{5}$ respectively) (Fig. 7 ).

TD-single point calculations were performed to determine the excitation probabilities of $\mathbf{2 a}, \mathbf{2} \mathbf{d}$ and $\mathbf{2 e}$ (Table 3 ). Of interest is the relevant excitation from HOMO to LUMO. Further calculated transitions and the calculated UV-Vis spectra are shown in the ESI. $\uparrow$ Notably, the probability of a HOMO-LUMO transition with $2 \%$ for ligand $2 \mathbf{a}$ is significantly lower than for 2d and 2e with 24 and 31\%, respectively. The calculated probability is also in correlation with the quantum yield, as $2 \mathbf{a}$ is the least and $2 \mathrm{e}$ the most fluorescent ligand.

To determine the wavelength of a possible fluorescence, the energy difference between the energy after excitation and the energy after relaxation (applying excited state geometry) was calculated and transformed to a wavelength (Table 4). The calculated emission wavelengths of $2 \mathbf{d}$ and $2 \mathbf{e}$ are 420 and $489 \mathrm{~nm}$, respectively. In contrast the emission wavelength of the naphthalene-based ligand $2 \mathbf{a}$ is calculated to be in the IR region at $2000 \mathrm{~nm}$.
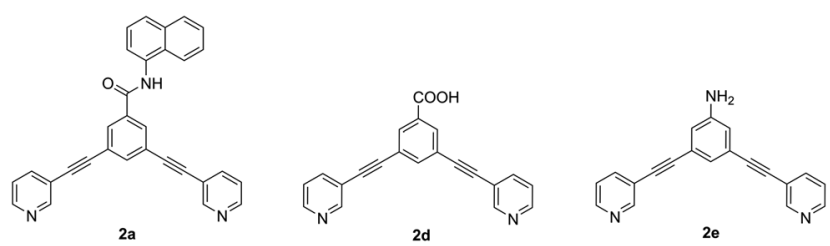

Fig. 7 Structure of ligands $2 a, 2 d$ and $2 \mathrm{e}$ used for computational studies.

Table 3 TD-DFT calculated absorption - HOMO $\rightarrow$ LUMO transitions

\begin{tabular}{lllll}
\hline Compound & $\begin{array}{l}\lambda(\mathrm{abs}) \\
{[\mathrm{nm}]}\end{array}$ & Probability & $\begin{array}{l}\text { Origin } \\
(\mathrm{MO})\end{array}$ & $\begin{array}{l}\text { Destination } \\
(\mathrm{MO})\end{array}$ \\
\hline 2a & 360.27 & 0.0184 & 117 & 118 \\
2d & 346.06 & 0.2358 & 84 & 85 \\
2e & 359.87 & 0.3099 & 77 & 78
\end{tabular}


Table 4 TD-DFT calculated emission - energy difference between the non-relaxed excited state $A$ (in ground state geometry) and the nonrelaxed ground state B (in optimized excited state geometry) and the corresponding emission wavelength

\begin{tabular}{lrrrc}
\hline Compound & State A (a.u.) & State B (a.u.) & $\Delta E(\mathrm{eV})$ & $\lambda(\mathrm{em})[\mathrm{nm}]$ \\
\hline 2a & -1432.137122 & -1432.159841 & 0.6181 & 2000 \\
2d & -1067.250746 & -1067.358863 & 2.9420 & 420 \\
2e & -934.038722 & -934.131580 & 2.5268 & 489
\end{tabular}

According to the obtained results, the low fluorescence of 2a compared to $\mathbf{2 d}$ and $2 \mathbf{e}$ is attributable to two factors. First, a HOMO-LUMO excitation is less likely for $2 \mathbf{a}$ than for the other two compounds. Second, the energy differences between the highest excited state and the non-relaxed ground state reveal no emission of $\mathbf{2 a}$ in the visible region if emission arises between these states. In contrast, $2 \mathbf{d}$ and $\mathbf{2 e}$ emit light in the visible part, with the calculated wavelengths being slightly longer than those of the absorbed photons.

Taking into consideration the geometry of the excited state compared to the pure ground state, an explanation for the emission properties of 2 a can be proposed (Fig. 8). In the ground state, the amide bond is almost planar with a dihedral angle of $177^{\circ}$ from the centered benzene ring to the naphthalene substituent. However, in the excited state, this angle is reduced to $99^{\circ}$, thus the amide bond is nearly orthogonal. Therefore, the chromophoric system is disrupted leading to a higher energy difference between the lowest point that can be
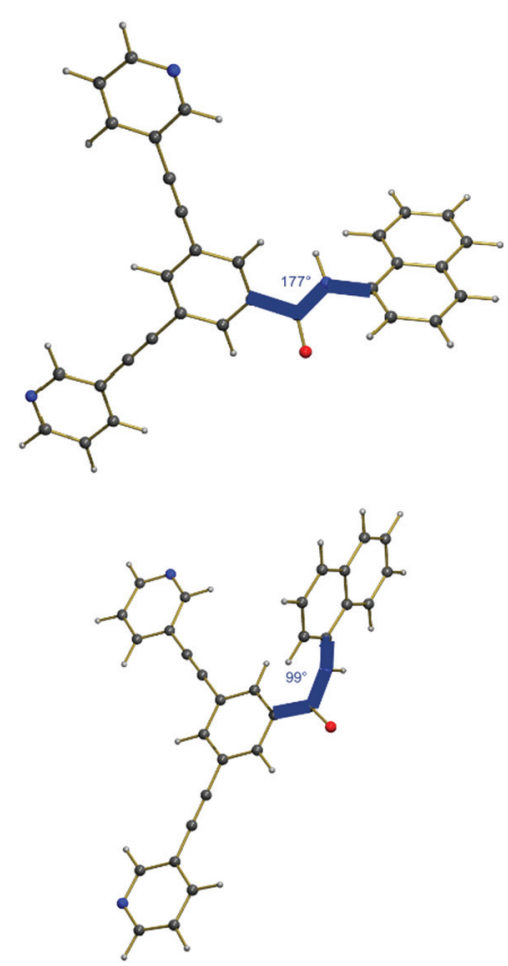

Fig. 8 Ground state of $2 a$ (top) and the optimized first excited state after light absorption (bottom). reached after fluorescence and the relaxed ground state. Accordingly, a smaller amount of energy is converted into light by emission resulting in a higher wavelength outside the visible region.

\section{Anticancer activity}

The antiproliferative effects of the coordination cages 1a-d, the ligands $\mathbf{2 a}-\mathbf{d}$ and the palladium precursor were evaluated against the human cancer cell lines A549 (lung carcinoma) and SKOV-3 (ovarian carcinoma) using the 3-(4,5-dimethylthiazol-2-yl)-2,5-diphenyltetrazolium bromide (MTT) assay. The $\mathrm{IC}_{50}$ (inhibitory concentration to reduce viability to $50 \%$ ) values of the compounds are presented in Table 5 in comparison with cisplatin.

Overall, the fluorophore-based cages 1a-c are more toxic for all tested cancer cells than cisplatin with the anthracenyltagged 1c being the most cytotoxic, and the naphthyl-tagged 1a the least. The corresponding ligands alone elicit low to moderate antiproliferative activities against the tested cancer cells, with the exception of ligand $2 \mathbf{b}\left(\mathrm{IC}_{50} \mathrm{ca} .3 .8 \mu \mathrm{M}\right)$. The latter is the only ligand bearing a pyridyl moiety as the central aromatic scaffold, which appears to induce a pronounced cytotoxic effect compared to the benzyl moiety of ligand 2a. The carboxy-based complex 1d, however, is less effective in cell lines A549 and SKOV-3 compared to cisplatin. Notably, the palladium precursor $\left[\mathrm{Pd}\left(\mathrm{NCCH}_{3}\right)_{4}\right]\left(\mathrm{BF}_{4}\right)_{2}$ and the bidentate ligand 2d are inactive $\left(\mathrm{IC}_{50}>100 \mu \mathrm{M}\right)$ for the selected cell lines. Based on previous investigations, ${ }^{5}$ cage compound 1d can possibly function as a drug delivery system for cisplatin due to its encapsulation properties and its low cytotoxicity. The encapsulation of cisplatin within cage $1 \mathbf{d}$ has been studied by ${ }^{1} \mathrm{H}$ NMR spectroscopy. The obtained spectrum (see Fig. S15 $\dagger$ ) shows that the inward directed proton signals of the benzyl proton $\mathrm{H}_{\mathrm{e}}$ undergo significant downfield shifts upon encapsulation of two equivalents of cisplatin, while broadening of the proton signals takes place, in accordance with previous observations. ${ }^{5}$ Cage 1d encapsulating cisplatin $\left(\mathrm{IC}_{50}=12.8 \pm 1.2 \mu \mathrm{M}\right)$ has

Table 5 Effects of cages, ligands, Pd precursor and cisplatin on cell viability in human lung carcinoma A549 and in human ovarian cancer cell line SKOV-3 after $72 \mathrm{~h}$ incubation

\begin{tabular}{lcc}
\hline & $\mathrm{IC}_{50}{ }^{a}[\mu \mathrm{M}]$ & \\
\cline { 2 - 3 } Compound & $\mathrm{A} 549$ & $\mathrm{SKOV}-3$ \\
\hline Cage 1a & $5.9 \pm 1.4$ & $8.0 \pm 1.4$ \\
Ligand 2a & $35.7 \pm 5.9$ & $46.6 \pm 11.0$ \\
Cage 1b & $1.4 \pm 0.5$ & $1.2 \pm 0.7$ \\
Ligand 2b & $3.8 \pm 0.4$ & $5.4 \pm 2.1$ \\
Cage 1c & $1.1 \pm 0.3$ & $1.1 \pm 0.6$ \\
Ligand 2c & $11.3 \pm 0.8$ & $23.6 \pm 6.2$ \\
Cage 1d & $82.6 \pm 15.1$ & $94.4 \pm 7.9$ \\
Ligand 2d & $>100$ & $>100$ \\
{$\left[(\text { Cisplatin })_{2} \subset \mathbf{1 d}\right]$} & - & $12.8 \pm 1.2$ \\
$\left.[\text { Pd(NCCH })_{4}\right]\left(\mathrm{BF}_{4}\right)_{2}$ & $>100$ & $>100$ \\
Cisplatin & $8.9 \pm 4.2$ & $15.4 \pm 2.2$ \\
${ }^{a}$ Mean $\pm \mathrm{SD}$ of at least three independent measurements. &
\end{tabular}


slightly more potent anticancer activity than cisplatin alone in SKOV-3. These preliminary results hold promise for the development of new $\mathrm{Pd}_{2} \mathrm{~L}_{4}$ cages as drug delivery systems.

Interestingly, the fluorophore-based ligands, especially $\mathbf{2 b}$, and the respective cages can act as anticancer drugs alone, although their imaging in cancer cells via fluorescence microscopy may not be possible in pharmacologically relevant concentrations.

\section{Conclusions}

A series of exo-functionalized $\mathrm{Pd}_{2} \mathrm{~L}_{4}$ coordination cages coupled to fluorophore moieties has been prepared and characterized including their photophysical properties. The fluorophore-based compounds were compared with a carboxyfunctionalized system in terms of their emission properties and anticancer activity in cancer cell lines. Interestingly, the carboxy-based ligand exhibits a higher fluorescence quantum yield than the ligands attached to fluorescent tags. The quenching of the fluorescence in these systems can be explained by TD-DFT calculations, showing a lower probability for HOMO-LUMO transitions and emission in the IR region (2000 nm). The cage compounds attached to fluorophore groups display a higher cytotoxicity in all tested cancer cells than cisplatin, making them suitable as anticancer agents. In contrast, cage 1d has a very low anticancer activity with respect to the cell lines A549 and SKOV-3, which may still make it suitable as a non-toxic drug delivery system for cisplatin or other drugs, and ongoing studies in our group are exploring this possibility. As a matter of fact preliminary cytotoxicity data on the $\left[(\text { cisplatin })_{2} \subset \mathbf{1 d}\right]$ system reinforce the relevance of our strategy. Other fluorophore-based ligands and corresponding metallocages are currently under investigation in our laboratories, where the length of the linker between the bipyridyl ligands and the fluorescent tags is increased to avoid the predicted torsion of the amide bond angle in the excited state. Finally, it should be pointed out that still the mechanisms of anticancer action of metallocages have not yet been clarified in most cases, although a few studies suggest different modes of action with respect to cisplatin, for instance palladium helicates induce the disruption of the cell membrane. ${ }^{15 a}$

\section{Experimental}

\section{General remarks}

All reagents were purchased from commercial sources and used without further purification. Chromatographic separations were performed using silica gel $(60-200 \mu \mathrm{m})$. NMR spectra were recorded with a Bruker Avance DPX 400 or a Bruker Avance III 400 or a Bruker Avance I 500 spectrometer at a temperature of $298 \mathrm{~K}$. The spectra were referenced to the residual ${ }^{1} \mathrm{H}$ and ${ }^{13} \mathrm{C}\left\{{ }^{1} \mathrm{H}\right\}$ signals of the solvents in parts per million (ppm). Abbreviations for NMR multiplicities are: singlet (s), doublet (d), triplet $(\mathrm{t})$, multiplet $(\mathrm{m})$. Coupling constants $J$ are given in Hz. The IR spectra were collected on a Varian ATR-FTIR instrument. Electrospray ionization (ESI) and fast atomic bombardment (FAB) mass spectra were obtained on a Thermo Scientific LCQ/Fleet spectrometer and a Finnigan MAT spectrometer, respectively. UV-Vis absorption spectra were acquired with a Jasco V-550 UV-Vis spectrometer.

\section{General procedure for the synthesis of dibromo derivatives}

Acid (1.0 equiv.), amine (1.0 equiv.), $N$-(3-dimethylaminopropyl)- $N$ '-ethylcarbodiimide hydrochloride (1.2 equiv.) and 4-dimethylaminopyridine $(10 \mathrm{~mol} \%)$ were dissolved in dry dichloromethane and stirred under an argon atmosphere at room temperature for $2 \mathrm{~h}$. To the reaction mixture, $2 \mathrm{M} \mathrm{HCl}$ $(40 \mathrm{~mL})$ was added and the aqueous phase was extracted three times with dichloromethane $(40 \mathrm{~mL})$. The organic phase was dried over $\mathrm{MgSO}_{4}$ and concentrated under reduced pressure. The crude product was recrystallized in dichloromethane to yield dibromide as a solid.

3,5-Dibromo- $\boldsymbol{N}$-(naphthalen-1-yl)benzamide 3a. A mixture of 3,5-dibromobenzoic acid (280 $\mathrm{mg}, 1.00 \mathrm{mmol}$ ), 1-naphthylamine (143 mg, $1.00 \mathrm{mmol})$, EDC (230 mg, $1.20 \mathrm{mmol})$ and DMAP (12.2 $\mathrm{mg}, 0.10 \mathrm{mmol})$ in dichloromethane $(15 \mathrm{~mL})$ yielded $3 a$ (218 mg, $0.54 \mathrm{mmol}, 54 \%$ ) as a white solid. ${ }^{1} \mathrm{H}$ NMR (400 MHz, $\left.\left[\mathrm{D}_{6}\right] \mathrm{DMSO}\right): \delta[\mathrm{ppm}]=10.63(\mathrm{~s}, 1 \mathrm{H}, \mathrm{NH}), 8.26(\mathrm{~d}$, $\left.J=1.6 \mathrm{~Hz}, 2 \mathrm{H}, \mathrm{H}_{\mathrm{b}}\right), 8.14\left(\mathrm{t}, J=1.7 \mathrm{~Hz}, 1 \mathrm{H}, \mathrm{H}_{\mathrm{a}}\right), 8.01-7.97(\mathrm{~m}$, $2 \mathrm{H}, \mathrm{H}_{\text {naph }}$ ), 7.89 (d, $\left.J=7.8 \mathrm{~Hz}, 1 \mathrm{H}, \mathrm{H}_{\text {naph }}\right), 7.60-7.54(\mathrm{~m}, 4 \mathrm{H}$, $\left.\mathrm{H}_{\text {naph }}\right) \cdot{ }^{13} \mathrm{C} \mathrm{NMR}\left(101 \mathrm{MHz},\left[\mathrm{D}_{6}\right] \mathrm{DMSO}\right): \delta[\mathrm{ppm}]=163.4$, $138.0,136.3,133.8,133.3,129.8,129.0,128.1,126.7,126.2$, 126.1, 125.5, 123.9, 123.4, 122.7. IR (solid): $\nu\left[\mathrm{cm}^{-1}\right]=3442$, 2840, 1637, 1521, 1346, 1280, 863, 773, 734, 665, 557, 485. MS (ESI, MeCN): $m / z=405.99[\mathrm{M}+\mathrm{H}]^{+}$(calcd for $\mathrm{C}_{17} \mathrm{H}_{12} \mathrm{Br}_{2} \mathrm{NO}$ : 405.93).

2,6-Dibromo- $N$-(naphthalen-1-yl)isonicotinamide $3 \mathrm{~b}$. A mixture of 2,6-dibromopyridine-4-carboxylic acid $(562 \mathrm{mg}$, $2.00 \mathrm{mmol}$ ), 1-naphthylamine (286 mg, $2.00 \mathrm{mmol}$ ), EDC (460 $\mathrm{mg}, 2.40 \mathrm{mmol}$ ) and DMAP $(24.4 \mathrm{mg}, 0.20 \mathrm{mmol})$ in dichloromethane $(20 \mathrm{~mL}$ ) yielded $3 \mathbf{b}(798 \mathrm{mg}, 1.97 \mathrm{mmol}$, $98 \%$ ) as a purple solid. ${ }^{1} \mathrm{H}$ NMR (400 MHz, [D 6 DMSO): $\delta$ $[\mathrm{ppm}]=10.81(\mathrm{~s}, 1 \mathrm{H}, \mathrm{NH}), 8.27\left(\mathrm{~s}, 2 \mathrm{H}, \mathrm{H}_{\mathrm{a}}\right), 8.06-7.98(\mathrm{~m}, 2 \mathrm{H}$, $\left.\mathrm{H}_{\text {naph }}\right), 7.90$ (d, $\left.J=8.1 \mathrm{~Hz}, 1 \mathrm{H}, \mathrm{H}_{\text {naph }}\right), 7.64-7.55(\mathrm{~m}, 4 \mathrm{H}$, $\left.\mathrm{H}_{\text {naph }}\right) \cdot{ }^{13} \mathrm{C} \mathrm{NMR}\left(101 \mathrm{MHz},\left[\mathrm{D}_{6}\right] \mathrm{DMSO}\right): \delta[\mathrm{ppm}]=162.0$, $147.0,140.6,134.2$, 133.7, 132.6, 128.7, 128.1, 126.9, 126.3, 126.2, 125.9, 125.5, 123.7, 123.3. IR (solid): $\nu\left[\mathrm{cm}^{-1}\right]=3442$, 2915, 1641, 1519, 1351, 1297, 1155, 873, 775, 694, 611, 555, 491. MS (FAB): $m / z=406.5[\mathrm{M}+\mathrm{H}]^{+}$(calcd for $\mathrm{C}_{16} \mathrm{H}_{11} \mathrm{Br}_{2} \mathrm{~N}_{2} \mathrm{O}$ : 406.9).

$\mathrm{N}$-(Anthracen-2-yl)-3,5-dibromobenzamide 3c. A mixture of 3,5-dibromobenzoic acid (280 $\mathrm{mg}, 1.00 \mathrm{mmol}$ ), 2-aminoanthracene (193 mg, $1.00 \mathrm{mmol}$ ), EDC (230 mg, $1.20 \mathrm{mmol}$ ) and DMAP (12.2 $\mathrm{mg}, 0.10 \mathrm{mmol})$ in dichloromethane $(20 \mathrm{~mL})$ yielded $3 a$ (415 mg, $0.91 \mathrm{mmol}, 91 \%)$ as a green solid. ${ }^{1} \mathrm{H}$ NMR (400 MHz, [D $\left.\left.\mathrm{D}_{6}\right] \mathrm{DMSO}\right): \delta[\mathrm{ppm}]=10.67(\mathrm{~s}, 1 \mathrm{H}, \mathrm{NH}), 8.63(\mathrm{~s}$, $\left.1 \mathrm{H}, \mathrm{H}_{\text {anth }}\right), 8.53$ (d, $\left.J=6.4 \mathrm{~Hz}, 2 \mathrm{H}, \mathrm{H}_{\text {anth }}\right), 8.22$ (d, $J=1.7 \mathrm{~Hz}$, $\left.2 \mathrm{H}, \mathrm{H}_{\mathrm{b}}\right), 8.13-8.06\left(\mathrm{~m}, 4 \mathrm{H}, \mathrm{H}_{\mathrm{a}}, \mathrm{H}_{\mathrm{anth}}\right), 7.79(\mathrm{dd}, J=1.9$, $\left.9.1 \mathrm{~Hz}, 1 \mathrm{H}, \mathrm{H}_{\text {anth }}\right), 7.53-7.46\left(\mathrm{~m}, 2 \mathrm{H}, \mathrm{H}_{\mathrm{anth}}\right) .{ }^{13} \mathrm{C} \mathrm{NMR}$ (101 MHz, [D 6 DMSO): $\delta[\mathrm{ppm}]=162.9,138.4,136.3,135.7$, 
$131.7,131.4,130.7,129.8,128.8,128.7,128.1,127.8,125.9$, $125.7,125.4,125.2,122.7,121.6,115.8$. IR (solid): $\nu\left[\mathrm{cm}^{-1}\right]=$ 3770, 2915, 1639, 1511, 1309, 1257, 1097, 887, 734, 663, 605, 474. $\mathrm{MS}(\mathrm{FAB}): m / z=279.8[\mathrm{M}-\text { anthracene }+2 \mathrm{H}]^{2+}$ (calcd for $\mathrm{C}_{7} \mathrm{H}_{6} \mathrm{Br}_{2} \mathrm{NO}$ : 279.9), $297.2[\mathrm{M}-2 \mathrm{Br}+2 \mathrm{H}]^{2+}$ (calcd for $\mathrm{C}_{21} \mathrm{H}_{15} \mathrm{NO}$ : 297.1).

\section{General procedure for the synthesis of ligands}

Dibromide (1.0 equiv.), 3-ethynylpyridine (4.0 equiv.), $\left[\mathrm{Pd}\left(\mathrm{PPh}_{3}\right)_{2} \mathrm{Cl}_{2}\right](10 \mathrm{~mol} \%)$ and $\mathrm{CuI}(10 \mathrm{~mol} \%)$ were added to degassed triethylamine and heated under an argon atmosphere at $70{ }^{\circ} \mathrm{C}$. After 72 hours, the reaction mixture was diluted with ethyl acetate $(50 \mathrm{~mL})$ and filtered over celite. The solvent was removed under reduced pressure and the crude residue was further purified by column chromatography $\left(\mathrm{CH}_{2} \mathrm{Cl}_{2}: \mathrm{MeOH}=100: 5\right)$ to give the ligand as a solid.

Ligand 2a. A mixture of dibromide 3a (182 mg, $0.45 \mathrm{mmol})$, 3-ethynylpyridine $(186 \mathrm{mg}, \quad 1.80 \mathrm{mmol}), \quad\left[\mathrm{Pd}\left(\mathrm{PPh}_{3}\right)_{2} \mathrm{Cl}_{2}\right]$ (31.6 mg, $0.05 \mathrm{mmol}$ ) and CuI $(8.60 \mathrm{mg}, 0.05 \mathrm{mmol})$ in triethylamine $(10 \mathrm{~mL})$ yielded $2 \mathrm{a}(135 \mathrm{mg}, 0.30 \mathrm{mmol}, 67 \%)$ as a light yellow solid. ${ }^{1} \mathrm{H}$ NMR (400 MHz, $\left.\left[\mathrm{D}_{6}\right] \mathrm{DMSO}\right): \delta[\mathrm{ppm}]=$ $10.68(\mathrm{~s}, 1 \mathrm{H}, \mathrm{NH}), 8.84\left(\mathrm{~s}, 2 \mathrm{H}, \mathrm{H}_{\mathrm{a}}\right), 8.64(\mathrm{~d}, J=4.4 \mathrm{~Hz}, 2 \mathrm{H}$, $\left.\mathrm{H}_{\mathrm{b}}\right), 8.34\left(\mathrm{~s}, 2 \mathrm{H}, \mathrm{H}_{\mathrm{f}}\right), 8.07-7.98\left(\mathrm{~m}, 5 \mathrm{H}, \mathrm{H}_{\mathrm{e}}, \mathrm{H}_{\mathrm{d}}, \mathrm{H}_{\text {naph }}\right), 7.90$ (d, $\left.J=8.0 \mathrm{~Hz}, 1 \mathrm{H}, \mathrm{H}_{\text {naph }}\right), 7.64-7.56$ (m, $\left.4 \mathrm{H}, \mathrm{H}_{\text {naph }}\right), 7.52$ (dd, $\left.J=7.8,5.0 \mathrm{~Hz}, 2 \mathrm{H}, \mathrm{H}_{\mathrm{c}}\right)$. DOSY NMR (400 MHz, [D 6 DMSO): $D\left[\mathrm{~m}^{2} \mathrm{~s}^{-1}\right]=2.02 \times 10^{-10} \cdot{ }^{13} \mathrm{C}$ NMR $\left(101 \mathrm{MHz},\left[\mathrm{D}_{6}\right] \mathrm{DMSO}\right):$ $\delta[\mathrm{ppm}]=164.5,151.8,149.5,138.8,136.7,135.8,133.8,133.5$, 131.2 , 129.1, 128.1, 126.6, 126.2, 126.1, 125.6, 124.0, 123.8, 123.4, 122.9, 118.9, 90.6, 87.8. IR (solid): $\nu\left[\mathrm{cm}^{-1}\right]=3467,3181$, 2873, 1639, 1521, 1268, 1020, 892, 792, 700, 626, 539. MS (ESI, MeCN/DMSO): $m / z=450.31[\mathrm{M}+\mathrm{H}]^{+}$(calcd for $\mathrm{C}_{31} \mathrm{H}_{20} \mathrm{~N}_{3} \mathrm{O}$ : 450.16).

Ligand $2 \mathbf{b}$. A mixture of dibromide $3 \mathbf{b}(183 \mathrm{mg}, 0.45 \mathrm{mmol})$, 3-ethynylpyridine (186 mg, $1.80 \mathrm{mmol}), \quad\left[\mathrm{Pd}\left(\mathrm{PPh}_{3}\right)_{2} \mathrm{Cl}_{2}\right]$ (31.6 mg, $0.05 \mathrm{mmol}$ ) and CuI $(8.60 \mathrm{mg}, 0.05 \mathrm{mmol})$ in triethylamine $(10 \mathrm{~mL})$ yielded $2 \mathbf{b}(146 \mathrm{mg}, 0.32 \mathrm{mmol}, 72 \%)$ as a yellow solid. ${ }^{1} \mathrm{H}$ NMR (400 MHz, $\left.\left[\mathrm{D}_{6}\right] \mathrm{DMSO}\right): \delta[\mathrm{ppm}]=10.87$ $(\mathrm{s}, 1 \mathrm{H}, \mathrm{NH}), 8.90\left(\mathrm{~s}, 2 \mathrm{H}, \mathrm{H}_{\mathrm{a}}\right), 8.68\left(\mathrm{~d}, J=4.1 \mathrm{~Hz}, 2 \mathrm{H}, \mathrm{H}_{\mathrm{b}}\right), 8.33$ $\left(\mathrm{s}, 2 \mathrm{H}, \mathrm{H}_{\mathrm{e}}\right), 8.13\left(\mathrm{~d}, J=7.9 \mathrm{~Hz}, 2 \mathrm{H}, \mathrm{H}_{\mathrm{d}}\right), 8.09-7.99(\mathrm{~m}, 2 \mathrm{H}$, $\mathrm{H}_{\text {naph }}$ ), 7.92 (d, $\left.J=8.0 \mathrm{~Hz}, 1 \mathrm{H}, \mathrm{H}_{\text {naph }}\right), 7.67-7.53\left(\mathrm{~m}, 6 \mathrm{H}, \mathrm{H}_{\mathrm{c}}\right.$, $\mathrm{H}_{\text {naph }}$ ). DOSY NMR (400 MHz, $\left.\left[\mathrm{D}_{6}\right] \mathrm{DMSO}\right): D\left[\mathrm{~m}^{2} \mathrm{~s}^{-1}\right]=1.76 \times$ $10^{-10} .{ }^{13} \mathrm{C}$ NMR (101 MHz, [D 6 DMSO): $\delta[\mathrm{ppm}]=163.3,152.1$, $150.1,143.3$, 143.1, 139.3, 133.8, 133.0, 128.9, 128.2, 126.9, $126.3,126.2$, 125.6, 125.4, 123.9, 123.4, 118.2, 90.7, 86.8. IR (solid): $\nu\left[\mathrm{cm}^{-1}\right]=3052,2915,1673,1533,1407,1268,1022$, 763, 698, 624, 495. MS (ESI, MeCN/DMSO): $\mathrm{m} / z=451.38$ $[\mathrm{M}+\mathrm{H}]^{+}$(calcd for $\mathrm{C}_{30} \mathrm{H}_{19} \mathrm{~N}_{4} \mathrm{O}: 451.16$ ).

Ligand 2c. A mixture of dibromide $3 \mathbf{c}(130 \mathrm{mg}, 0.29 \mathrm{mmol})$, 3-ethynylpyridine $(118 \mathrm{mg}, 1.16 \mathrm{mmol}), \quad\left[\mathrm{Pd}\left(\mathrm{PPh}_{3}\right)_{2} \mathrm{Cl}_{2}\right]$ (20.0 $\mathrm{mg}, 0.03 \mathrm{mmol})$ and $\mathrm{CuI}(5.50 \mathrm{mg}, 0.03 \mathrm{mmol})$ in triethylamine $(10 \mathrm{~mL})$ yielded $2 \mathrm{c}(26.7 \mathrm{mg}, 0.05 \mathrm{mmol}, 18 \%)$ as a light brown solid. ${ }^{1} \mathrm{H}$ NMR (400 MHz, [D 6 DMSO): $\delta[\mathrm{ppm}]=$ $10.73(\mathrm{~s}, 1 \mathrm{H}, \mathrm{NH}), 8.84\left(\mathrm{~s}, 2 \mathrm{H}, \mathrm{H}_{\mathrm{a}}\right), 8.67-8.65\left(\mathrm{~m}, 3 \mathrm{H}, \mathrm{H}_{\mathrm{b}}\right.$, $\mathrm{H}_{\text {anth }}$ ), 8.54-8.53 (m, $\left.2 \mathrm{H}, \mathrm{H}_{\text {anth }}\right), 8.28\left(\mathrm{~s}, 2 \mathrm{H}, \mathrm{H}_{\mathrm{f}}\right), 8.13-8.06$ ( $\left.\mathrm{m}, 6 \mathrm{H}, \mathrm{H}_{\mathrm{d}}, \mathrm{H}_{\mathrm{e}}, \mathrm{H}_{\mathrm{anth}}\right)$, 7.85-7.82 (m, $\left.1 \mathrm{H}, \mathrm{H}_{\mathrm{anth}}\right), 7.53-7.47$ $\left(\mathrm{m}, 4 \mathrm{H}, \mathrm{H}_{\mathrm{c}}, \mathrm{H}_{\mathrm{anth}}\right)$. DOSY NMR (400 MHz, [D $\left.\left.\mathrm{D}_{6}\right] \mathrm{DMSO}\right)$ :
$D\left[\mathrm{~m}^{2} \mathrm{~s}^{-1}\right]=1.77 \times 10^{-10} \cdot{ }^{13} \mathrm{C} \mathrm{NMR}\left(101 \mathrm{MHz},\left[\mathrm{D}_{6}\right] \mathrm{DMSO}\right): \delta$ $[\mathrm{ppm}]=164.4,151.6,149.4,144.5,139.3$, 134.8, 134.5, 134.2, $133.3,131.3,128.9,128.7,128.5$, 128.2, 127.9, 126.9, 126.8, 126.0, 125.9, 125.0, 124.1, 123.0, 119.1, 117.3, 90.7, 87.9. IR (solid): $\nu\left[\mathrm{cm}^{-1}\right]=3282,3085,2956,1643,1477,1284,1020$, 885, 802, 742, 700, 626, 470. MS (ESI, MeCN/DMSO): $\mathrm{m} / \mathrm{z}=$ $500.34[\mathrm{M}+\mathrm{H}]^{+}$(calcd for $\mathrm{C}_{35} \mathrm{H}_{22} \mathrm{~N}_{3} \mathrm{O}: 500.18$ ).

Ligand 2d. A mixture of 3,5-dibromobenzoic acid (271 mg, $0.97 \mathrm{mmol})$, 3-ethynylpyridine (400 $\mathrm{mg}, 3.88 \mathrm{mmol})$, $\left[\mathrm{Pd}\left(\mathrm{PPh}_{3}\right)_{2} \mathrm{Cl}_{2}\right](68.1 \mathrm{mg}, 0.10 \mathrm{mmol})$ and $\mathrm{CuI}(18.5 \mathrm{mg}$, $0.10 \mathrm{mmol})$ in triethylamine $(15 \mathrm{~mL})$ yielded $2 \mathrm{~d}(54.2 \mathrm{mg}$, $0.17 \mathrm{mmol}, 17 \%$ ) as a white solid after recrystallization in dichloromethane. ${ }^{1} \mathrm{H}$ NMR (400 MHz, $\left.\left[\mathrm{D}_{6}\right] \mathrm{DMSO}\right): \delta[\mathrm{ppm}]=$ $8.82\left(\mathrm{~d}, J=1.9 \mathrm{~Hz}, 2 \mathrm{H}, \mathrm{H}_{\mathrm{a}}\right), 8.63\left(\mathrm{dd}, J=1.7,4.9 \mathrm{~Hz}, 2 \mathrm{H}, \mathrm{H}_{\mathrm{b}}\right.$ ), $8.12\left(\mathrm{~d}, J=1.6 \mathrm{~Hz}, 2 \mathrm{H}, \mathrm{H}_{\mathrm{f}}\right), 8.08-8.01\left(\mathrm{~m}, 3 \mathrm{H}, \mathrm{H}_{\mathrm{d}}, \mathrm{H}_{\mathrm{e}}\right), 7.50$ (dd, $J=4.8,7.6 \mathrm{~Hz}, 2 \mathrm{H}, \mathrm{H}_{\mathrm{c}}$ ). DOSY NMR (400 MHz, [D DMSO): $D\left[\mathrm{~m}^{2} \mathrm{~s}^{-1}\right]=2.02 \times 10^{-10} \cdot{ }^{13} \mathrm{C} \mathrm{NMR}\left(101 \mathrm{MHz},\left[\mathrm{D}_{6}\right]\right.$ DMSO): $\delta[\mathrm{ppm}]=165.8,151.9,149.5,138.9,137.6,132.4$, 123.8, 123.0, 118.9, 90.3, 87.9. IR (solid): $\nu\left[\mathrm{cm}^{-1}\right]=3519,2827$, 1589, 1261, 1164, 1043, 800, 692, 642, 457. MS (ESI, MeCN/ DMSO): $m / z=325.31[\mathrm{M}+\mathrm{H}]^{+}$(calcd for $\mathrm{C}_{21} \mathrm{H}_{13} \mathrm{~N}_{2} \mathrm{O}_{2}$ : 325.10 ).

\section{General procedure for the synthesis of cages}

A solution of $\left[\mathrm{Pd}\left(\mathrm{NCCH}_{3}\right)_{4}\right]\left(\mathrm{BF}_{4}\right)_{2} \quad(2.0$ equiv. $)$ and ligand (4.0 equiv.) in DMSO was stirred at RT for one hour. After precipitation by addition of acetone and diethyl ether, the solid was filtered and washed with acetone and diethyl ether to yield the cage compound as a solid.

Cage 1a. $\left[\mathrm{Pd}\left(\mathrm{NCCH}_{3}\right)_{4}\right]\left(\mathrm{BF}_{4}\right)_{2}(22.2 \mathrm{mg}, 0.05 \mathrm{mmol})$ and $2 \mathrm{a}$ (45.0 $\mathrm{mg}, 0.10 \mathrm{mmol}$ ) in DMSO (2 mL) gave 1a $(44.7 \mathrm{mg}$, $0.02 \mathrm{mmol}, 76 \%)$ as a light brown solid. ${ }^{1} \mathrm{H}$ NMR $(400 \mathrm{MHz}$, [D $\left.\left.\mathrm{D}_{6}\right] \mathrm{DMSO}\right): \delta[\mathrm{ppm}]=10.72(\mathrm{~s}, 1 \mathrm{H}, \mathrm{NH}), 9.67\left(\mathrm{~s}, 2 \mathrm{H}, \mathrm{H}_{\mathrm{a}}\right), 9.45$ $\left(\mathrm{d}, J=5.8 \mathrm{~Hz}, 2 \mathrm{H}, \mathrm{H}_{\mathrm{b}}\right), 8.45\left(\mathrm{~d}, J=1.5 \mathrm{~Hz}, 2 \mathrm{H}, \mathrm{H}_{\mathrm{f}}\right), 8.35(\mathrm{~d}, J=$ $\left.8.0 \mathrm{~Hz}, 2 \mathrm{H}, \mathrm{H}_{\mathrm{d}}\right), 8.21$ (s, $1 \mathrm{H}, \mathrm{H}_{\mathrm{e}}$ ), 8.00-7.96 (m, $2 \mathrm{H}, \mathrm{H}_{\text {naph }}$ ), 7.91-7.86 (m, $3 \mathrm{H}, \mathrm{H}_{\mathrm{c}}, \mathrm{H}_{\text {naph }}$ ), 7.57-7.52 (m, $\left.4 \mathrm{H}, \mathrm{H}_{\text {naph }}\right)$. DOSY NMR (400 MHz, [D $]$ DMSO): $D\left[\mathrm{~m}^{2} \mathrm{~s}^{-1}\right]=8.97 \times 10^{-11}$. ${ }^{13} \mathrm{C}$ NMR (101 MHz, [D 6 DMSO): $\delta[\mathrm{ppm}]=164.1,153.0,150.9$, 143.1 , 136.4, 136.2, 133.8, 133.3, 132.5, 129.0, 128.2, 127.5, 126.8, 126.2 126.1, 125.6, 124.0, 123.3, 122.2, 122.1, 93.3, 86.0. ${ }^{11} \mathrm{~B}$ NMR (128 MHz, [D 6 DMSO): $\delta[\mathrm{ppm}]=-1.07 .{ }^{19} \mathrm{~F}$ NMR $\left(377 \mathrm{MHz},\left[\mathrm{D}_{6}\right] \mathrm{DMSO}\right): \delta[\mathrm{ppm}]=-147.78\left({ }^{10} \mathrm{BF}_{4}{ }^{-}\right),-147.83$ $\left({ }^{11} \mathrm{BF}_{4}{ }^{-}\right)$. MS (ESI, DMSO/MeCN): $m / z=502.81\left[\mathrm{M}-4 \mathrm{BF}_{4}{ }^{-}\right]^{4+}$ (calcd for $\mathrm{Pd}_{2} \mathrm{C}_{124} \mathrm{H}_{76} \mathrm{~N}_{12} \mathrm{O}_{4}$ : 502.86), 699.58 $\left[\mathrm{M}-3 \mathrm{BF}_{4}{ }^{-}\right]^{3+}$ (calcd for $\mathrm{Pd}_{2} \mathrm{C}_{124} \mathrm{H}_{76} \mathrm{~N}_{12} \mathrm{O}_{4} \mathrm{BF}_{4}$ : 699.48).

Cage 1b. $\left[\mathrm{Pd}\left(\mathrm{NCCH}_{3}\right)_{4}\right]\left(\mathrm{BF}_{4}\right)_{2}(22.2 \mathrm{mg}, 0.05 \mathrm{mmol})$ and $2 \mathbf{b}$ (45.1 $\mathrm{mg}, 0.10 \mathrm{mmol})$ in DMSO $(2 \mathrm{~mL})$ gave 1b $(47.8 \mathrm{mg}$, $0.02 \mathrm{mmol}, 81 \%)$ as a light brown solid. ${ }^{1} \mathrm{H}$ NMR $(400 \mathrm{MHz}$, [D $\left.\left.{ }_{6}\right] \mathrm{DMSO}\right): \delta[\mathrm{ppm}]=10.89(\mathrm{~s}, 1 \mathrm{H}, \mathrm{NH}), 9.66\left(\mathrm{~s}, 2 \mathrm{H}, \mathrm{H}_{\mathrm{a}}\right), 9.44$ $\left(\mathrm{d}, J=5.7 \mathrm{~Hz}, 2 \mathrm{H}, \mathrm{H}_{\mathrm{b}}\right), 8.42-8.40\left(\mathrm{~m}, 4 \mathrm{H}, \mathrm{H}_{\mathrm{e}}, \mathrm{H}_{\mathrm{d}}\right), 8.01-7.88$ $\left(\mathrm{m}, 5 \mathrm{H}, \mathrm{H}_{\mathrm{c}}, \mathrm{H}_{\text {naph }}\right), 7.59-7.53\left(\mathrm{~m}, 4 \mathrm{H}, \mathrm{H}_{\text {naph }}\right)$. DOSY NMR (400 MHz, [D 6 DMSO): $D\left[\mathrm{~m}^{2} \mathrm{~s}^{-1}\right]=8.80 \times 10^{-11} \cdot{ }^{13} \mathrm{C} \mathrm{NMR}$ (101 MHz, [D 6 DMSO): $\delta[\mathrm{ppm}]=162.9,153.6,151.3,143.6$, $143.4,142.6$, 133.8, 132.8, 130.6, 128.8, 127.5, 126.6, 126.3, $126.2, \quad 125.6, \quad 123.9, \quad 123.2, \quad 121.5,93.1, \quad 84.6 .{ }^{11} \mathrm{~B} \quad \mathrm{NMR}$ (128 MHz, [D 6 DMSO): $\delta[\mathrm{ppm}]=-1.28 .{ }^{19} \mathrm{~F}$ NMR $(377 \mathrm{MHz}$, $\left.\left[\mathrm{D}_{6}\right] \mathrm{DMSO}\right): \delta[\mathrm{ppm}]=-148.13\left({ }^{10} \mathrm{BF}_{4}{ }^{-}\right),-148.19\left({ }^{11} \mathrm{BF}_{4}{ }^{-}\right) . \mathrm{MS}$ 
(ESI, DMSO/MeCN): $m / z=503.52\left[\mathrm{M}-4 \mathrm{BF}_{4}{ }^{-}\right]^{4+}$ (calcd for $\mathrm{Pd}_{2} \mathrm{C}_{120} \mathrm{H}_{72} \mathrm{~N}_{16} \mathrm{O}_{4}$ : 503.85), $700.17\left[\mathrm{M}-3 \mathrm{BF}_{4}{ }^{-}\right]^{3+}$ (calcd for $\mathrm{Pd}_{2} \mathrm{C}_{120} \mathrm{H}_{72} \mathrm{~N}_{16} \mathrm{O}_{4} \mathrm{BF}_{4}$ : 700.80).

Cage 1c. $\left[\mathrm{Pd}\left(\mathrm{NCCH}_{3}\right)_{4}\right]\left(\mathrm{BF}_{4}\right)_{2}(13.3 \mathrm{mg}, 0.03 \mathrm{mmol})$ and $2 \mathrm{c}$ (30.0 $\mathrm{mg}, 0.06 \mathrm{mmol}$ ) in DMSO (2 mL) gave 1c $(24.1 \mathrm{mg}$, $0.01 \mathrm{mmol}, 63 \%)$ as a green solid. ${ }^{1} \mathrm{H}$ NMR $\left(400 \mathrm{MHz},\left[\mathrm{D}_{6}\right]\right.$ DMSO): $\delta[\mathrm{ppm}]=10.75(\mathrm{~s}, 1 \mathrm{H}, \mathrm{NH}), 9.66\left(\mathrm{~s}, 2 \mathrm{H}, \mathrm{H}_{\mathrm{a}}\right), 9.48(\mathrm{~d}$, $\left.J=5.9 \mathrm{~Hz}, 2 \mathrm{H}, \mathrm{H}_{\mathrm{b}}\right), 8.63-8.59\left(\mathrm{~m}, 1 \mathrm{H}, \mathrm{H}_{\text {anth }}\right), 8.54-8.48$ (m, $2 \mathrm{H}, \mathrm{H}_{\text {anth }}$ ), 8.39-8.28 (m, $\left.4 \mathrm{H}, \mathrm{H}_{\mathrm{f}}, \mathrm{H}_{\mathrm{d}}\right), 8.09-8.02\left(\mathrm{~m}, 4 \mathrm{H}, \mathrm{H}_{\mathrm{e}}\right.$, $\left.\mathrm{H}_{\text {anth }}\right), 7.92-7.86\left(\mathrm{~m}, 2 \mathrm{H}, \mathrm{H}_{\mathrm{c}}\right), 7.77$ (d, $\left.J=9.4 \mathrm{~Hz}, 1 \mathrm{H}, \mathrm{H}_{\text {anth }}\right)$, 7.52-7.46 (m, $\left.2 \mathrm{H}, \mathrm{H}_{\text {anth }}\right)$. DOSY NMR (400 MHz, [D 6 DMSO): $D$ $\left[\mathrm{m}^{2} \mathrm{~s}^{-1}\right]=8.05 \times 10^{-11} \cdot{ }^{11} \mathrm{~B} \mathrm{NMR}\left(128 \mathrm{MHz},\left[\mathrm{D}_{6}\right] \mathrm{DMSO}\right): \delta$ $[\mathrm{ppm}]=-1.30 .{ }^{19} \mathrm{~F}$ NMR $\left(377 \mathrm{MHz},\left[\mathrm{D}_{6}\right] \mathrm{DMSO}\right): \delta[\mathrm{ppm}]=$ $-148.13\left({ }^{10} \mathrm{BF}_{4}{ }^{-}\right),-148.19\left({ }^{11} \mathrm{BF}_{4}{ }^{-}\right)$. MS (ESI, DMSO/MeCN): $m / z=552.43\left[\mathrm{M}-4 \mathrm{BF}_{4}{ }^{-}\right]^{4+}$ (calcd for $\mathrm{Pd}_{2} \mathrm{C}_{140} \mathrm{H}_{84} \mathrm{~N}_{12} \mathrm{O}_{4}$ : 552.87). Note: this complex is too insoluble to obtain a ${ }^{13} \mathrm{C}$ NMR spectrum.

Cage 1d. $\left[\mathrm{Pd}\left(\mathrm{NCCH}_{3}\right)_{4}\right]\left(\mathrm{BF}_{4}\right)_{2}(22.2 \mathrm{mg}, 0.05 \mathrm{mmol})$ and 2d $(32.4 \mathrm{mg}, 0.10 \mathrm{mmol})$ in DMSO $(2 \mathrm{~mL})$ gave 1d $(35.4 \mathrm{mg}$, $0.02 \mathrm{mmol}, 76 \%) .{ }^{1} \mathrm{H}$ NMR (400 MHz, [D 6 DMSO): $\delta[\mathrm{ppm}]=9.67$ $\left(\mathrm{s}, 2 \mathrm{H}, \mathrm{H}_{\mathrm{a}}\right), 9.38$ (d, $\left.J=5.7 \mathrm{~Hz}, 2 \mathrm{H}, \mathrm{H}_{\mathrm{b}}\right), 8.35$ (d, $J=7.8 \mathrm{~Hz}, 2 \mathrm{H}$, $\left.\mathrm{H}_{\mathrm{d}}\right), 8.21\left(\mathrm{~s}, 2 \mathrm{H}, \mathrm{H}_{\mathrm{f}}\right) 8.10\left(\mathrm{~s}, 1 \mathrm{H}, \mathrm{H}_{\mathrm{e}}\right), 7.85$ (dd, $J=5.8,7.8 \mathrm{~Hz}$, $2 \mathrm{H}, \mathrm{H}_{\mathrm{c}}$ ). DOSY NMR (400 MHz, $\left.\left[\mathrm{D}_{6}\right] \mathrm{DMSO}\right): D\left[\mathrm{~m}^{2} \mathrm{~s}^{-1}\right]=8.71 \times$ $10^{-11} \cdot{ }^{11} \mathrm{~B}$ NMR $\left(128 \mathrm{MHz},\left[\mathrm{D}_{6}\right] \mathrm{DMSO}\right): \delta[\mathrm{ppm}]=-1.22 . \mathrm{MS}$ (ESI, DMSO/MeCN): $m / z=377.96\left[\mathrm{M}-4 \mathrm{BF}_{4}{ }^{-}\right]^{4+}$ (calcd for $\mathrm{Pd}_{2} \mathrm{C}_{84} \mathrm{H}_{48} \mathrm{~N}_{8} \mathrm{O}_{8}$ : 377.54), 532.42 $\left[\mathrm{M}-3 \mathrm{BF}_{4}{ }^{-}\right]^{3+}$ (calcd for $\mathrm{Pd}_{2} \mathrm{C}_{84} \mathrm{H}_{48} \mathrm{~N}_{8} \mathrm{O}_{8} \mathrm{BF}_{4}$ : 532.39). Note: this complex is too insoluble to obtain a ${ }^{13} \mathrm{C}$ NMR spectrum.

\section{Crystallographic details}

For detailed information see the ESI. $\uparrow$ Crystallographic Data (excluding structure factors) for the structure reported in this paper has been deposited with the Cambridge Crystallographic Data Centre as supplementary publication no. CCDC 1454096 (1b).

\section{Fluorescence spectroscopy and determination of quantum yield}

The emission spectra were recorded on a Varian Cary Eclipse fluorescence spectrophotometer. For each compound, dilutions in DMSO at a concentration of $10 \mu \mathrm{M}$ were prepared. First, UV-Vis spectra of compounds were recorded in DMSO, to determine the wavelength of the absorbance maximum. The absorbance maximum should be between 0.3 and 1 . The measured absorbance wavelength was used as the excitation wavelength for fluorescence microscopy.

For the determination of quantum yields, ${ }^{23,24}$ the choice of the right quantum standard is important. Depending on the excitation and emission wavelengths of the compounds, quinine sulfate or naphthalene was used as a standard. Different dilutions of the compounds and standards were prepared in DMSO and sulfuric acid or cyclohexane, respectively. Absorbance spectra were recorded using three different concentrated solutions, not exceeding an absorbance of 0.1 to minimize reabsorption effects. The same solutions were used for recording the fluorescence spectra. The excitation wave- length should be the same for the compound and standard. In addition, all fluorescence spectra must be recorded with constant excitation and emission slits. The quantum yield of a compound was calculated using the Stokes Einstein equation. $^{24}$

\section{Computational details}

All calculations have been carried out by using the GAUSSIAN 09 D.01 package. ${ }^{25}$ The hybrid functional $\mathrm{B} 3 \mathrm{LYP}^{26,27}$ has been chosen together with the basis set $6-31+\mathrm{G}^{*} \cdot{ }^{28-30}$ For the excited states optimization, a time-dependent DFT formalism ${ }^{31,32}$ has been applied using the B3LYP functional. All calculations have been performed in solution with PCM as an implicit solvation model and DMSO as a solvent.

\section{Cell viability assay (MTT assay)}

Human lung cancer cell line A549 and human ovarian cancer cell line SKOV-3 were obtained from the European Centre of Cell Cultures (ECACC, Salisbury, UK) and maintained in culture as described by the provider. The cells were cultured in DMEM (Dulbecco's Modified Eagle Medium) containing 10\% fetal bovine serum (FBS) and 1\% penicillin/streptomycin at $37{ }^{\circ} \mathrm{C}$ and $5 \% \mathrm{CO}_{2}$. For evaluation of growth inhibition, cells were seeded in 96-well plates at a concentration of 11000 cells per well and grown for $24 \mathrm{~h}$ in complete medium. Solutions of the compounds with the required concentration (0.5 to $150 \mu \mathrm{M})$ were prepared by diluting a freshly prepared stock solution $\left(10^{-2} \mathrm{M}\right.$ in DMSO) of the corresponding compound in aqueous DMEM medium. $200 \mu \mathrm{L}$ of the dilutions were added to each well and the cells were incubated for $72 \mathrm{~h}$. Following drug exposure, 3-(4,5-dimethylthiazol-2-yl)-2,5-diphenyltetrazolium bromide (MTT) was added to the cells at a final concentration of $0.5 \mathrm{mg} \mathrm{mL}^{-1}$ and incubated for $2 \mathrm{~h}$. Afterwards the culture medium was removed and violet formazan was dissolved in DMSO. The optical density was quantified in tetraplicates at $550 \mathrm{~nm}$ using a multi-well plate reader. The percentage of surviving cells was calculated from the ratio of absorbance of treated to untreated cells. The $\mathrm{IC}_{50}$ values were calculated as inhibitory concentration of cell growth at $50 \%$ by plotting the percentage of surviving cells against the drug concentration and presented as mean $\pm \mathrm{SE}$ of at least three independent experiments.

\section{Acknowledgements}

A. C. acknowledges support from Cardiff University and the August-Wilhelm Scheer Visiting Professorship at the Technical University of Munich. Authors acknowledge the support of the Technische Universität München - Institute for Advanced Study, funded by the German Excellence Initiative and the European Union Seventh Framework Programme under grant agreement no. 291763. A. S. is grateful to Boehringer Ingelheim Fonds for financial support. EU COST action CM1105 is gratefully acknowledged for funding and fruitful discussion. A. S. and M. H. are grateful for the financial 
support of the TUM Graduate School of Chemistry. The authors thank Leibnitz Rechenzentrum of the Bavarian Academy of Science for provision of computing time. Dr Alexander Pöthig's support with crystallographic data is greatly appreciated.

\section{Notes and references}

1 T. R. Cook and P. J. Stang, Chem. Rev., 2015, 115, 70017045.

2 M. Han, D. M. Engelhard and G. H. Clever, Chem. Soc. Rev., 2014, 43, 1848-1860.

3 (a) M. D. Pluth, R. G. Bergman and K. N. Raymond, Acc. Chem. Res., 2009, 42, 1650-1659; (b) D. M. Vriezema, M. Comellas Aragonès, J. A. A. W. Elemans, J. J. L. M. Cornelissen, A. E. Rowan and R. J. M. Nolte, Chem. Rev., 2005, 105, 1445-1490; (c) M. Yoshizawa, J. K. Klosterman and M. Fujita, Angew. Chem., Int. Ed., 2009, 48, 3418-3438; (d) S. H. A. M. Leenders, R. GramageDoria, B. de Bruin and J. N. H. Reek, Chem. Soc. Rev., 2015, 44, 433-448.

4 (a) R. Chakrabarty, P. S. Mukherjee and P. J. Stang, Chem. Rev., 2011, 111, 6810-6918; (b) T. R. Cook, V. Vajpayee, M. H. Lee, P. J. Stang and K.-W. Chi, Acc. Chem. Res., 2013, 46, 2464-2474.

5 A. Schmidt, V. Molano, M. Hollering, A. Pöthig, A. Casini and F. E. Kühn, Chem. - Eur. J., 2016, 22, 2253-2256.

6 B. Therrien, G. Süss-Fink, P. Govindaswamy, A. K. Renfrew and P. J. Dyson, Angew. Chem., Int. Ed., 2008, 47, 37733776.

7 (a) Y.-R. Zheng, K. Suntharalingam, T. C. Johnstone and S. J. Lippard, Chem. Sci., 2015, 6, 1189-1193; (b) O. Zava, J. Mattsson, B. Therrien and P. J. Dyson, Chem. - Eur. J., 2010, 16, 1428-1431; (c) A. Pitto-Barry, N. P. E. Barry, O. Zava, R. Deschenaux, P. J. Dyson and B. Therrien, Chem. - Eur. J., 2011, 17, 1966-1971; (d) F. Schmitt, J. Freudenreich, N. P. E. Barry, L. Juillerat-Jeanneret, G. Süss-Fink and B. Therrien, J. Am. Chem. Soc., 2012, 134, 754-757; (e) J. Mattsson, O. Zava, A. K. Renfrew, Y. Sei, K. Yamaguchi, P. J. Dyson and B. Therrien, Dalton Trans., 2010, 39, 8248-8255; $(f)$ N. P. E. Barry, O. Zava, P. J. Dyson and B. Therrien, Chem. - Eur. J., 2011, 17, 96699677.

8 (a) H. Ahmad, D. Ghosh and J. A. Thomas, Chem. Commun., 2014, 50, 3859-3861; (b) R. Kieltyka, P. Englebienne, J. Fakhoury, C. Autexier, N. Moitessier and H. F. Sleiman, J. Am. Chem. Soc., 2008, 130, 10040-10041; (c) A. Mishra, S. Ravikumar, S. H. Hong, H. Kim, V. Vajpayee, H. Lee, B. Ahn, M. Wang, P. J. Stang and K.-W. Chi, Organometallics, 2011, 30, 6343-6346; (d) N. P. E. Barry, N. H. Abd Karim, R. Vilar and B. Therrien, Dalton Trans., 2009, 10717-10719.

9 (a) A. Mishra, S. Chang Lee, N. Kaushik, T. R. Cook, E. H. Choi, N. Kumar Kaushik, P. J. Stang and K.-W. Chi, Chem. - Eur. J., 2014, 20, 14410-14420; (b) A. Dubey, J. W. Min, H. J. Koo, H. Kim, T. R. Cook, S. C. Kang,
P. J. Stang and K.-W. Chi, Chem. - Eur. J., 2013, 19, 1162211628; (c) A. Garci, A. A. Dobrov, T. Riedel, E. Orhan, P. J. Dyson, V. B. Arion and B. Therrien, Organometallics, 2014, 33, 3813-3822; (d) G. Gupta, J. Kumar, A. Garci, N. Nagesh and B. Therrien, Molecules, 2014, 19, 6031-6046; (e) G. Gupta, B. Murray, P. Dyson and B. Therrien, Materials, 2013, 6, 5352-5366; $(f)$ A. Mishra, Y. J. Jeong, J.-H. Jo, S. C. Kang, M. S. Lah and K.-W. Chi, ChemBioChem, 2014, 15, 695-700.

10 V. Grishagin, J. B. Pollock, S. Kushal, T. R. Cook, P. J. Stang and B. Z. Olenyuk, Proc. Natl. Acad. Sci. U. S. A., 2014, 111, 18448-18453.

11 V. Vajpayee, Y. J. Yang, S. C. Kang, H. Kim, I. S. Kim, M. Wang, P. J. Stang and K.-W. Chi, Chem. Commun., 2011, 47, 5184-5186.

12 A. Schmidt, A. Casini and F. E. Kühn, Coord. Chem. Rev., 2014, 275, 19-36.

13 (a) R. Sekiya, M. Fukuda and R. Kuroda, J. Am. Chem. Soc., 2012, 134, 10987-10997; (b) M. Han, R. Michel, B. He, Y.-S. Chen, D. Stalke, M. John and G. H. Clever, Angew. Chem., Int. Ed., 2013, 52, 1319-1323; (c) G. H. Clever, W. Kawamura, S. Tashiro, M. Shiro and M. Shionoya, Angew. Chem., Int. Ed., 2012, 51, 2606-2609; (d) S. Freye, J. Hey, A. Torras-Galán, D. Stalke, R. Herbst-Irmer, M. John and G. H. Clever, Angew. Chem., Int. Ed., 2012, 51, 21912194; (e) S. Freye, R. Michel, D. Stalke, M. Pawliczek, H. Frauendorf and G. H. Clever, J. Am. Chem. Soc., 2013, 135, 8476-8479.

14 (a) N. Kishi, M. Akita and M. Yoshizawa, Angew. Chem., Int. Ed., 2014, 53, 3604-3607; (b) N. Kishi, Z. Li, K. Yoza, M. Akita and M. Yoshizawa, J. Am. Chem. Soc., 2011, 133, 11438-11441; (c) J. E. M. Lewis, E. L. Gavey, S. A. Cameron and J. D. Crowley, Chem. Sci., 2012, 3, 778-784; (d) J. E. M. Lewis, C. John McAdam, M. G. Gardiner and J. D. Crowley, Chem. Commun., 2013, 49, 3398-3400; (e) P. Liao, B. W. Langloss, A. M. Johnson, E. R. Knudsen, F. S. Tham, R. R. Julian and R. J. Hooley, Chem. Commun., 2010, 46, 4932-4934; (f) S. Löffler, J. Lübben, L. Krause, D. Stalke, B. Dittrich and G. H. Clever, J. Am. Chem. Soc., 2015, 137, 1060-1063; ( $g$ ) M. Yamashina, M. M. Sartin, Y. Sei, M. Akita, S. Takeuchi, T. Tahara and M. Yoshizawa, J. Am. Chem. Soc., 2015, 137, 9266-9269.

15 (a) S. M. McNeill, D. Preston, J. E. M. Lewis, A. Robert, K. Knerr-Rupp, D. O. Graham, J. R. Wright, G. I. Giles and J. D. Crowley, Dalton Trans., 2015, 44, 11129-11136; (b) A. Ahmedova, D. Momekova, M. Yamashina, P. Shestakova, G. Momekov, M. Akita and M. Yoshizawa, Chem. - Asian J., 2016, 11, 474-477.

16 (a) J. K. Klosterman, Y. Yamauchi and M. Fujita, Chem. Soc. Rev., 2009, 38, 1714-1725; (b) B. J. Holliday and C. A. Mirkin, Angew. Chem., Int. Ed., 2001, 40, 2022-2043; (c) M. Fujita, M. Tominaga, A. Hori and B. Therrien, Acc. Chem. Res., 2005, 38, 369-378.

17 A. M. Johnson, O. Moshe, A. S. Gamboa, B. W. Langloss, J. F. K. Limtiaco, C. K. Larive and R. J. Hooley, Inorg. Chem., 2011, 50, 9430-9442. 
18 (a) J. E. M. Lewis, A. B. S. Elliott, C. J. McAdam, K. C. Gordon and J. D. Crowley, Chem. Sci., 2014, 5, 18331843; (b) Z. Li, N. Kishi, K. Hasegawa, M. Akita and M. Yoshizawa, Chem. Commun., 2011, 47, 8605-8607.

19 K. Y. Zhang and K. K.-W. Lo, Metal Complexes for Cell and Organism Imaging, In Inorganic Chemical Biology, John Wiley \& Sons Ltd, 2014.

20 M. Wenzel, A. de Almeida, E. Bigaeva, P. Kavanagh, M. Picquet, P. Le Gendre, E. Bodio and A. Casini, Inorg. Chem., 2016, 55, 2544-2557.

21 (a) A. Citta, E. Schuh, F. Mohr, A. Folda, M. L. Massimino, A. Bindoli, A. Casini and M. P. Rigobello, Metallomics, 2013, 5, 1006; (b) D. C. Crans, E. Nordlander, B. Bertrand, A. de Almeida, E. P. M. van der Burgt, M. Picquet, A. Citta, A. Folda, M. P. Rigobello, P. Le Gendre, E. Bodio and A. Casini, Eur. J. Inorg. Chem., 2014, 2014, 4532-4536; (c) M. Patra and G. Gasser, ChemBioChem, 2012, 13, 12321252.

22 (a) Y. Cohen, L. Avram and L. Frish, Angew. Chem., Int. Ed., 2005, 44, 520-554; (b) D. Li, G. Kagan, R. Hopson and P. G. Williard, J. Am. Chem. Soc., 2009, 131, 5627-5634.

23 (a) D. F. Eaton, J. Photochem. Photobiol., B, 1988, 2, 523531; (b) S. Fery-Forgues and D. Lavabre, J. Chem. Educ., 1999, 76, 1260-1264.

24 A. T. Rhys Williams and S. A. Winfield, Analyst, 1983, 108, 1067-1071.

25 M. J. Frisch, G. W. Trucks, H. B. Schlegel, G. E. Scuseria, M. A. Robb, J. R. Cheeseman, G. Scalmani, V. Barone, B. Mennucci, G. A. Petersson, H. Nakatsuji, M. Caricato,
X. Li, H. P. Hratchian, A. F. Izmaylov, J. Bloino, G. Zheng, J. L. Sonnenberg, M. Hada, M. Ehara, K. Toyota, R. Fukuda, J. Hasegawa, M. Ishida, T. Nakajima, Y. Honda, O. Kitao, H. Nakai, T. Vreven, J. A. Montgomery Jr., J. E. Peralta, F. Ogliaro, M. Bearpark, J. J. Heyd, E. Brothers, K. N. Kudin, V. N. Staroverov, R. Kobayashi, J. Normand, K. Raghavachari, A. Rendell, J. C. Burant, S. S. Iyengar, J. Tomasi, M. Cossi, N. Rega, J. M. Millam, M. Klene, J. E. Knox, J. B. Cross, V. Bakken, C. Adamo, J. Jaramillo, R. Gomperts, R. E. Stratmann, O. Yazyev, A. J. Austin, R. Cammi, C. Pomelli, J. W. Ochterski, R. L. Martin, K. Morokuma, V. G. Zakrzewski, G. A. Voth, P. Salvador, J. J. Dannenberg, S. Dapprich, A. D. Daniels, Ö. Farkas, J. B. Foresman, J. V. Ortiz, J. Cioslowski and D. J. Fox, Gaussian 09, Revision D.01, Gaussian, Inc., Wallingford, CT, 2009.

26 A. D. Becke, J. Chem. Phys., 1993, 98, 5648-5652.

27 C. Lee, W. Yang and R. G. Parr, Phys. Rev. B: Condens. Matter, 1988, 37, 785-789.

28 R. Ditchfield, W. J. Hehre and J. A. Pople, J. Chem. Phys., 1971, 54, 724-728.

29 T. Clark, J. Chandrasekhar, G. W. Spitznagel and P. v. R. Schleyer, J. Comput. Chem., 1983, 4, 294-301.

30 M. J. Frisch, J. A. Pople and J. S. Binkley, J. Chem. Phys., 1984, 80, 3265-3269.

31 G. Scalmani, M. J. Frisch, B. Mennucci, J. Tomasi, R. Cammi and V. Barone, J. Chem. Phys., 2006, 124, 1-15.

32 M. E. Casida, C. Jamorski, K. C. Casida and D. R. Salahub, J. Chem. Phys., 1998, 108, 4439-4449. 